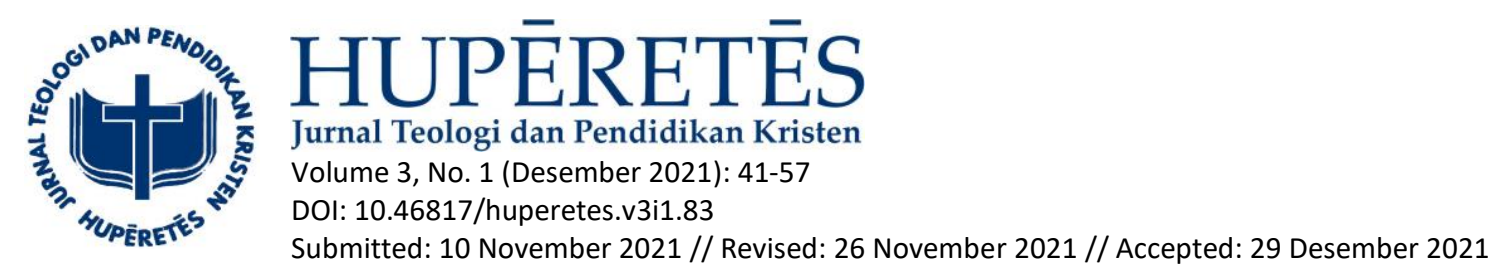

\title{
Kompetensi Interpersonal Paulus Sebagai Pemimpin Pastoral
}

\author{
Franky \\ Sekolah Tinggi Teologi Kalimantan - Pontianak \\ Korepondensi: frankytambuh9@gmail.com
}

\begin{abstract}
Abstrak: Gereja sebagai salah satu bentuk organisasi organik (hidup) membutuhkan pemimpin pastoral yang mampu menjalankan tugas dan tanggung jawab secara profesional. Kemampuan dalam menjalankan tugas dan tanggung jawab tersebut menyangkut kompetensi interpersonal yang dimiliki oleh seorang pemimpin pastoral. Apabila memperhatikan dinamika kepemimpinan gereja pada saat ini, maka gereja tidak lepas dari krisis kepemimpinan, secara khusus berkaitan dengan kompetensi interpersonal pemimpin gereja. Pada akhirnya, hal ini berdampak negatif dalam pelayanan. Penelitian ini bertujuan untuk menjelaskan bahwa kompetensi interpersonal seorang pemimpin sangat dibutuhkan dalam pelayanan pastoral. Adapun metode yang digunakan dalam penelitian adalah metode deskriptif dengan teknik pengumpulan data menggunakan metode studi literatur dan hermeneutik alkitabiah. Akhirnya, melalui penelitian ini ditemukan bahwa merujuk dari pelayanan Rasul Paulus, dengan menyoroti pelayanannya dari segala penjuru; dalam segala hal Paulus menunjukkan diri sebagai pelayan Allah yang memiliki kompetensi interpersonal. Teladan yang baik dalam pelayanan menunjukkan identitas kompetensi interpersonal Paulus sebagai pemimpin pastoral yang kuat dan berakar di dalam Kristus. Hal ini menjadikan Paulus seorang rasul yang dipakai Allah secara luar biasa serta berdampak, baik itu kepada pribadi-pribadi maupun kelompok-kelompok besar jemaat yang dilayaninya.
\end{abstract}

Kata kunci: interpersonal, kompetensi, Paulus, pemimpin pastoral

Abstract: The church as a form of organic (living) organization requires pastoral leaders who can carry out their duties and responsibilities professionally. The ability to carry out these duties and responsibilities concerns the interpersonal competence possessed by a pastoral leader. If you pay attention to the dynamics of church leadership at this time, the church cannot be separated from a leadership crisis, especially when it comes to the interpersonal competence of church leaders. In the end, this has a negative impact on service. The church, which should produce leaders who have interpersonal competence, is instead contaminated with various leadership problems; thus, impacting on service. This study aims to explain that the interpersonal competence of a leader is needed in pastoral care. The method used in this research is descriptive method with data collection techniques using literature study methods and biblical hermeneutics. Finally, through this research it was found that referring to the ministry of the Apostle Paul, who was highlighted by his ministry from all directions, showed himself to be a servant of God who had interpersonal competence. A good example in ministry shows the identity of Paul's interpersonal skills competence as a pastoral leader, who is strong and rooted in Christ. This makes Paul was greatly used by God and and had an impact, both to individuals and to the large groups of churches he served.

Keywords: interpersonal, competency, Paul, pastoral leader 


\section{PENDAHULUAN}

Kepemimpinan merupakan salah satu hal penting dalam pelayanan karena berimplikasi besar terhadap penggunaan otoritas dan perubahan. Dalam pelaksanaannya, gereja sebagai salah satu bentuk organisasi organik (hidup) membutuhkan pemimpin yang mampu menjalankan tugas dan tanggung jawab kepemimpinan (pastoral) secara profesional. $^{1}$ Kemampuan dalam menjalankan tugas dan tanggung jawab tersebut menyangkut kompetensi interpersonal yang dimiliki oleh seorang pemimpin pastoral. Hal ini berarti bahwa seorang pemimpin pastoral yang memiliki kompetensi interpersonal senantiasa menyadari bahwa setiap pelayanan harus dikerjakan secara profesional. Sebab, kaum profesional akan dinilai berdasarkan kompetensi kinerjanya dan bukan kesan yang muncul dari gelar profesional mereka. ${ }^{2}$ Dan seorang pemimpin pastoral yang berkompeten, akan menolong dirinya dan jemaat yang dilayani agar mengalami pertumbuhan, baik secara kualitas maupun kuantitas.

Pada dasarnya, kompetensi atau dalam bahasa Inggris competency secara leksikal berarti kewenangan untuk menentukan (memutuskan) sesuatu; secara linguistik adalah kemampuan untuk menguasai gramatika suatu bahasa secara abstrak atau batiniah. Kompeten (kata sifat; Ing.: competent) sendiri berarti cakap, berkuasa (memutuskan, menentukan sesuatu), berwewenang. ${ }^{3}$ Sedangkan Istilah interpersonal menurut Webster Third New International Dictionary memiliki pengertian:

"existing between personal situation in which speech occurs; relating to or involving personal and social relations out of which develop system of shared expectations, patters of emotional relatedness and modes of social adjustment."4

${ }^{1}$ Richard Clinton and Paul Leavenworth, Memulai Dengan Baik ((Jakarta: Penerbit Immanuel, 2004), 19.

${ }^{2}$ Joe E. Trull and James E. Carter, Etika Pelayan Gereja: Peran Moral Dan Tanggung Jawab Etis Pelayan Gereja (Jakarta: BPK Gunung Mulia, 2013), 25.

${ }^{3}$ Kamus Besar Bahasa Indonesia (Jakarta: Pusat Bahasa Departemen Pendidikan Nasional, Balai Pustaka, 2001), 584.
Jadi, kompetensi interpersonal adalah berbicara mengenai kapasitas dalam diri seseorang yang mencakup kualitas pengetahuan, karakter, dan keahlian yang diekspresikan ketika membangun relasi atau hubungan dengan sesama.

Apabila memerhatikan dinamika kepemimpinan gereja pada saat ini, maka gereja tidak lepas dari krisis kepemimpinan. Gereja yang seharusnya menghasilkan pemimpin yang memiliki kompetensi interpersonal, malah terkontaminasi dengan berbagai masalah kepemimpinan. Misalnya, dalam hal pengajaran firman Tuhan yang tidak berdasar pada prinsipprinsip hermeneutika yang benar, menghasilkan pengajaran firman Tuhan yang menyimpang dari kebenaran yang absolut. Adapun penyebabnya karena pemimpin gereja yang kurang memiliki semangat untuk mengembangkan kompetensi pengetahuannya melalui belajar firman Tuhan (teologi). Belum lagi permasalahan plagiarism. ${ }^{5}$ Dimana, oleh karena ingin mengambil 'jalan pintas' dalam mempersiapkan khotbah, pengkhotbah tidak mau direpotkan dengan persiapan yang benar dengan menggunakan prinsip hermeneutika yang benar pula. Hal ini berakibat pada diri pemimpin gereja, yang tidak mau jujur dan bertanggung jawab terhadap pengajaran yang disampaikan kepada jemaatnya.

Apabila melihat dari segi karakter, maka tidak sedikit ditemukan pemimpin gereja yang memiliki permasalahan dengan karakter kepribadian, secara khusus berkaitan dengan integritas diri pemimpin pastoral. Pada kenyataannya, masih ditemukan pemimpin gereja yang kurang menghargai dan bertanggung jawab terhadap pekerjaan atau pelayanan yang sudah dipercayakan. Hanya oleh karena "kesibukankesibukan" di luar gereja, maka pemimpin gereja kurang memiliki kepekaan, kesetiaan serta motivasi dalam mengerjakan tugas dan tanggung jawabnya di Gereja. Selanjutnya, pemimpin gereja

${ }^{4}$ Webster's New Encyclopedy Dictionary (New York: Black \& Dog Leventhal Publisher, 1993), 1961.

${ }^{5}$ Plagiarisme menurut Nolan Harmon adalah mengambil amanat orang lain dan mengakuinya sebagai milik sendiri. 
yang terlalu sibuk mengikuti aktivitas di luar gereja, berakibat pada kurangnya perhatian kepada anggota jemaat yang membutuhkan pelayanannya. Bahkan, ada jemaat yang mengeluhkan susahnya bertemu dengan pendeta atau majelis untuk pelayanan pastoral. Pemimpin gereja yang terlalu sibuk mengikuti aktivitas di luar gereja terkadang berpikir bahwa dengan sibuk di luar jemaat daripada melayani jemaat sendiri, maka kehebatannya akan diakui, sehingga pamornya cenderung naik. ${ }^{6}$ Implikasi lainnya dalam kehidupan jemaat bagi pemimpin gereja yang terlalu sibuk mengikuti aktivitas di luar gereja adalah tidak sedikit para pemimpin gereja yang tidak mengenal anggota jemaat yang dilayaninya.

Berdasarkan keahlian, masih terdapat pemimpin gereja yang kurang terampil, baik pada segi kemampuan manajerial maupun kemampuan berorganisasi. Dalam pelayanan di bidang organisasi gereja, seorang pemimpin gereja seringkali dituntut oleh jemaatnya agar dapat mengelola administrasi dengan baik dan menjadi "manajer" yang baik. Banyak pemimpin gereja yang memiliki persoalan seperti ini. Pemimpin gereja tidak memiliki kecakapan dalam administrasi dan kemampuan manajerial. Akibatnya, tidak sedikit pemimpin gereja yang tidak dapat mengkoordinir anggota jemaatnya untuk terlibat aktif dalam melaksanakan programprogram gereja. Selain itu, dalam pelayanan konseling masih terdapat pemimpin gereja yang belum melihat pentingnya pelayanan ini. Hal ini nampak dalam pelaksanaannya yang asal saja dengan cara yang undisciplined dan unskilled. Akibatnya, permasalahan yang dihadapi oleh jemaat, tidak terselesaikan, dikarenakan pemimpin gereja yang tidak memiliki keahlian dan kemampuan dalam pelayanan konseling.

Untuk menjawab problematika tersebut diatas, ada beberapa artikel yang sudah membahas mengenai kompetensi pemimpin pastoral. $^{7}$

\footnotetext{
${ }^{6}$ Agus Wiyanto, Rapor Merah Pendeta (Yogyakarta: Gloria Graffa, 2010), 42.

${ }^{7}$ Tenny Sudibyo et al., "Implementasi Prinsip Kepemimpinan Rasul Paulus,” no. 2 (n.d.): 1-13; Pengembangan Yayasan and Mercy Indonesia, "Kepemimpinan Rasul Paulus Menurut Teks 1 Korintus 4 : 1-21 Dalam" 1 (2021): 83-94; Paus Paulus VI, "Humanae
}

Namun, beberapa artikel tersebut belum memberikan penjelasan yang spesifik mengenai kompetensi interpersonal Paulus sebagai pemimpin pastoral. Rasul Paulus yang disoroti pelayanannya dari segala penjuru, dalam segala hal ia menunjukkan diri sebagai pelayan Allah yang memiliki kompetensi interpersonal. Teladan yang baik dalam pelayanan menunjukkan identitas Paulus sebagai pemimpin pastoral yang kuat dan berakar di dalam Kristus dan membuat dia menjadi seorang rasul Rasul Paulus dipakai Allah dalam pelayanan pastoral kepada pribadi maupun jemaat-jemaat yang pernah dilayaninya. yang dipakai Allah secara luar biasa serta diperlengkapi oleh Allah dalam karunia-karunia penggembalaan, baik itu kepada pribadi-pribadi maupun kelompok-kelompok besar jemaat yang dilayaninya. Bertolak dari beberapa persoalan yang telah dipaparkan di atas, maka hal ini mendorong penulis untuk mengkaji mengenai Kompetensi Interpersonal Paulus sebagai Pemimpin Pastoral. Dengan menemukan kompetensi interpersonal Paulus sebagai pemimpin pastoral, diharapkan dapat memberikan kontribusi bagi peningkatan kompetensi interpersonal pemimpin gereja pada masa kini.

\section{METODE}

Penelitian ini merupakan kajian literatur atau kajian pustaka yang memuat bahasan mengenai kompetensi interpersonal Paulus sebagai pemimpin pastoral dengan menerapkan metode deskriptif. Metode deskriptif adalah pencarian fakta dengan interpretasi yang tepat. ${ }^{8}$ Metode deskriptif bertujuan untuk menggambarkan secara tepat mengenai sifat suatu individu, keadaan, gejala atau hal-hal yang khusus dalam masyarakat. ${ }^{9}$ Adapun Teknik pengumpulan data pada penelitian ini dengan metode studi literatur dan hermeneutik alkitabiah. Metode studi

Vitae: Encycal on the Right Ordering of Procreation Children," Acta Apostolociae Sedis 6012 (1968).

${ }^{8}$ Mohammad Nazir, Metode Penelitian (Jakarta: Gloria Indonesia, 1985), 63.

${ }^{9}$ Usman Rianse, Metodologi Penelitian Sosial Dan Ekonomi: Teori Dan Aplikasi (Bandung: CV. Alfabeta, 2008), 26-27. 
literatur (pustaka) menggunakan teknik pengumpulan data melalui sumber tertulis, terdiri dari buku-buku, artikel, majalah, laporan, dan data tertulis lainnya yang terkait dengan masalah penelitian. ${ }^{10}$ Sedangkan metode hermeneutik dilakukan dengan analisis naratif. Analisis naratif merupakan suatu metode untuk memahami dan mengkomunikasikan pesan alkitabiah yang sesuai dengan bentuk kisah dan kesaksian personal (dalam hal ini Paulus), sesuatu yang merupakan ciri khas dari Kitab Suci dan suatu model fundamental dari komunikasi antarmanusia. ${ }^{11}$ Melalui studi literatur dan hermeneutika alkitabiah ini, peneliti melakukan langkahlangkah untuk menyelidiki beberapa teks Alkitab dalam Perjanjian Baru berkaitan dengan Paulus dan pelayanannya. Dari hasil penyelidikan tersebut, peneliti mengontruksi dan selanjutnya mendeskripsikan pokok pikiran mengenai kompetensi interpersonal Paulus sebagai pemimpin pastoral

\section{PEMBAHASAN}

Untuk memeroleh gambaran yang komprehensif mengenai kompetensi interpersonal Rasul Paulus sebagai pemimpin pastoral, maka akan dibahas terlebih dahulu mengenai kepemimpinan pastoral rasul Paulus.

\section{Kepemimpinan Pastoral Rasul Paulus}

Pemahaman tentang kepemimpinan pastoral Paulus tidak lepas dari keterlibatannya yang aktif dalam perjalanan misi untuk memberitakan Injil

${ }^{10}$ Lexy J. Moleong, Metodologi Penelitian Kualitatif, Edisi Revi. (Bandung: Penerbit PT Remaja Rosdakarya, 2010), 113.

${ }^{11}$ Petrus Alexander Didi Tarmedi, "Analisis Naratif: Sebuah Metode Hermeneutika Kristiani Kitab Suci," Melintas 29 (2013), 332.

${ }^{12}$ G. Sudarmanto, Menjadi Pelayan Krsitus Yang Baik (Palembang: Percetakan Monalisa, 2009), 106.

${ }^{13}$ Dari Paulus, hamba Kristus Yesus, yang dipanggil menjadi rasul dan dikuduskan untuk memberitakan Injil Allah (Rm. 1:1); Dari Paulus, yang oleh kehendak Allah dipanggil menjadi rasul Kristus Yesus ... (1 Kor. 1:1); dari Paulus, yang oleh kehendak Allah menjadi rasul Kristus Yesus (2 Kor. 1:1); Dari Paulus, seorang rasul, bukan karena manusia, juga bukan oleh seorang manusia, melainkan oleh yang akhirnya melahirkan komunitas-komunitas Kristen. ${ }^{12}$ Jadi dapat disimpulkan bahwa dalam perjalanan misinya, ada terdapat praktek kepemimpinan pastoral yang diterapkan oleh Paulus.

Untuk memperoleh deskripsi mengenai Paulus sebagai pemimpin pastoral, maka setidaknya ada dua pokok bahasan yang akan dijelaskan pada bagian ini, yakni: hakikat dan tujuan kepemimpinan pastoral serta pola kepemimpinan Paulus sebagai pemimpin pastoral.

\section{Hakikat dan Tujuan Kepemimpinan Pastoral}

Kepemimpinan pastoral merupakan suatu proses memberikan pengaruh yang dilakukan oleh pemimpin pastoral kepada pribadi atau sekelompok umat untuk menjalankan kehendak Allah bagi kelompok tersebut. Apabila memerhatikan pada kalimat pembuka dari beberapa surat pastoral yang ditulis oleh Paulus, ${ }^{13}$ hal tersebut menyatakan mengenai hakikat mengenai kepemimpinan Pastoral. Paulus menyadari bahwa panggilannya sebagai Rasul yang didalamnya melakukan tugas-tugas kepemimpinan pastoral, merupakan panggilan Ilahi. Hal ini bukan oleh karena kehendaknya sendiri atau oleh karena perintah manusia melainkan oleh Yesus Kristus dan Allah, Bapa, yang telah memilih serta menetapkannya untuk melakukan tugas tersebut. Ia meyakini bahwa Allah yang telah memanggil dan mengudus-

Yesus Kristus dan Allah, Bapa, yang telah membangkitkan Dia dari antara orang mati (Gal. 1:1); Dari Paulus, rasul Kristus Yesus oleh kehendak Allah, kepada orang-orang kudus di Efesus, orang-orang percaya dalam Kristus Yesus (Ef. 1:1); Dari Paulus dan Timotius, hamba-hamba Kristus Yesus (Flp. 1:1); Dari Paulus, rasul Kristus Yesus, oleh kehendak Allah ... (Kol. 1:1); Dari Paulus, rasul Kristus Yesus menurut perintah Allah, Juruselamat kita, dan Kristus Yesus, dasar pengharapan kita (1 Tim. 1:1); Dari Paulus, rasul Kristus Yesus oleh kehendak Allah untuk memberitakan janji tentang hidup dalam Kristus Yesus (2 Tim. 1:1); Dari Paulus, hamba Allah dan rasul Yesus Kristus untuk memelihara iman orang-orang pilihan Allah dan pengetahuan akan kebenaran seperti yang nampak dalam ibadah kita (Tit. 1:1). 
kannya untuk pelayanan kerasulan. ${ }^{14}$ Jadi, pada hakekatnya, kepemimpinan pastoral merupakan peran (inisiatif) Allah yang memanggil, menetapkan dan memperlengkapi seseorang untuk mengerjakan tugas dan tanggung jawab kepemimpinan sesuai dengan tujuan Allah.

Adapun tujuan dari kepemimpinan pastoral adalah agar anggota jemaat dan para pemimpin pastoral mengalami pertumbuhan yang berorientasi pada: pertama, pertumbuhan spiritual jemaat kepada pengenalan akan Kristus (band. Fil.3:10); kedua, pertumbuhan psikologis yang menyangkut perubahan karakter, emosi, moral; ketiga, pertumbuhan kualitas jemaat berhubungan dengan kelahiran baru yang berdampak pada pertumbuhan rohani dan keempat, pertumbuhan jemaat secara kuantitas. ${ }^{15}$ Jadi, tujuan kepemimpinan pastoral adalah jelas, selain adanya perubahan dan pertumbuhan berdasarkan kasih Kristus dalam diri pemimpin pastoral, juga kepada orang-orang yang dipimpin (jemaat). Keduanya sama-sama mengalami perubahan dan pertumbuhan di dalam Kristus dan dalam proses kepemimpinan pastoral selalu didasarkan atas kehendak Tuhan. Perubahan ini juga nampak dalam pribadi Paulus maupun person dan jemata-jemaat yang dilayaninya.

\section{Pola Kepemimpinan Pastoral Paulus}

Setiap pemimpin memiliki beragam pola dalam kepemimpinannya masing-masing. Hal ini bertujuan agar proses kepemimpinan dapat berjalan dengan baik dan tujuan yang ingin dicapai dapat terlaksana dengan baik pula. Berikut adalah pola-pola kepemimpinan Paulus sebagai pemimpin pastoral.

\section{Kepemimpinan Pelayan (Servanthood Leadership)}

Panggilan seorang pemimpin gereja adalah panggilan untuk melayani, bukan untuk dilayani dan menguasai. Pemimpin yang melayani adalah pemimpin yang sangat peduli atas pertumbuhan dan dinamika kehidupan pengikut, dirinya dan komunitasnya dan karenanya ia mendahulukan hal-hal tadi daripada pencapaian ambisi pribadi atau pola dan kesukaannya saja. Impiannya ialah agar orang yang dilayani tadi akan menjadi pemimpin yang melayani juga. ${ }^{16}$

Pada dasarnya, perjumpaan Paulus dengan Yesus mengubah caranya dalam memimpin. Sebelum bertobat, model kepemimpinan Paulus hanyalah untuk mendahulukan kepentingan pribadinya, yakni memuaskan kedagingannya dalam 'membela' keyakinan yang dianutnya. Namun, setelah bertobat dan meresponi panggilan Allah untuk melayani, ia menghambakan dirinya kepada Yesus. Sebagai hamba Kristus, Paulus tidak lagi memimpin dengan kehebatannya, namun Ia menjadi pemimpin yang melayani. Orientasi pelayanannya, selain mencintai setiap jiwa (Kis. 20:18-21, 26, 27), juga berorientasi dan berpusat pada Allah yang memercayakan pelayanan tersebut (Kis. 20:22-25).

Arti sederhana dari pelayan adalah siap sedia mengikuti dan melakukan perintah sang tuan. Bahkan walaupun demi melakukan tugas tersebut, kenyamanan atau pun jiwa kita dipertaruhkan. Inilah rahasia kepemimpinan Paulus sebagai pelayan. Hidupnya adalah untuk menuruti kehendak Allah dan nyawanya tidak dihiraukan sedikit pun demi menyenangkan sang Tuan (Flp. 1:21). Jadi, dalam menyikapi akan setiap karya Allah yang begitu sempurna dalam hal pemilihan dan pemanggilannya sebagai Rasul, memungkinkan Paulus melayani jemaat dengan menerapkan pola kepemimpinan pelayan. Paulus menyadari setelah bertobat, hubungannya yang baru dengan Allah mengakibatkan juga suatu hubungan yang baru dengan jemaat yang dilayaninya. Perhatian dan kepeduliannya terhadap dinamika kehidupan jemaat merupakan bukti nyata dari pola kepemimpinan pelayan yang diterapkan oleh Paulus.

\footnotetext{
${ }^{15}$ Yosafat Bangun, Integritas Pemimpin Pastoral (Yogyakarta: ANDI, 2010), 190-219.

${ }^{16}$ Ibid, 154-155.
} 


\section{Pola Pemuridan}

Di dalam pelayanannya, Paulus banyak menghabiskan waktunya untuk memenangkan orang-orang bagi Kristus. Selain itu, Paulus juga banyak menghabiskan waktunya mengajar dan menjelaskan kehidupan serta karya-karya Yesus Kristus. Paulus menyadari bahwa ia harus mengajar dan melatih jemaat-jemaat ini supaya mereka dapat bersatu, kuat dalam iman kepada Kristus. Para jemaat ini memiliki sebuah tanggung jawab untuk menyebarkan Injil ke seluruh penjuru dunia dan apabila mereka sendiri terpecah belah, maka mereka tidak akan mampu memberitakan Injil Yesus Kristus. ${ }^{17}$

Mengenai pola pemuridan yang dilakukan oleh Paulus, Ron Jenson dan Jim Stevens memberikan penjelasan lebih rinci, yakni:

Paulus juga mempraktikkan pemuridan teknis dalam usahanya mengembangkan para pemimpin gereja. Sepanjang kitab Kisah Para Rasul dan Suratsurat kiriman kita membaca hubungannya yang akrab dengan Timotius, Titus, Lukas, Silas dan yang lain. Intruksi Paulus kepada Timotius merupakan contoh khusus yang baik mengenai hubungan pemuridan yang kuat orang per-orang. Surat-surat Paulus kepadanya termasuk nasihat dan instruksi pribadi, tanpa ragu-ragu dipertegas dalam pembicaraan bertatap muka. ${ }^{18}$

Jadi, pola pemuridan ini sangat jelas dikerjakan oleh Paulus sebagai pemimpin Pastoral, yakni mempersiapkan jemaat, untuk menjadi pemberita-pemberita Injil kepada orang-orang yang belum percaya. Dan dalam hal ini, selain mewariskan pengetahuannya, Paulus juga mewariskan seluruh kehidupan dan teladannya.

\section{Pola Pendelegasian Tugas}

Berbicara mengenai pola pendelegasian tugas, sebelum mempercayakan suatu tugas, seorang pemimpin sudah memperhatikan faktor-faktor pendukung, apakah seseorang yang didelegasikan tugas tersebut, telah siap untuk melaksanakan tugas yang dipercayakan. Dalam pendelegasian tersebut, seorang pemimpin harus membuat perhitungan yang tepat, menyangkut kepribadian orang tersebut, kualitas, dan karunia rohani, bakat, dan kesanggupannya untuk mendapat tugas pendelegasian tersebut.

Berdasarkan tulisan-tulisan Paulus, setidaknya ada dua tokoh yang diberikan delegasi oleh Paulus untuk melayani jemaat yang sedang mengalami "masalah", yakni Timotius yang diutus melayani jemaat di Efesus dan Titus ke Korintus, Makedonia maupun Kreta. Pendelegasian tugas yang dilakukan oleh Paulus didasari oleh keyakinannya kepada setiap pribadi yang diberikan kepercayaan untuk melayani.

\section{Pola “Team Work”}

Kepemimpinan mengacu pada tindakan kolektif (team work), dirancang dengan suatu cara agar membawa perubahan yang signifikan sembari meningkatkan kompetensi dan motivasi dari semua yang terlibat. ${ }^{19}$ Apabila melihat pelayanan Paulus, ia bukanlah seorang yang single fighter. Single fighter adalah kiasan bagi seorang yang bekerja sendiri tanpa membutuhkan masukan atau bantuan dari orang lain. Paulus sebaliknya, ia adalah seorang pemimpin pastoral yang bekerja secara 'team work.' Paulus membutuhkan rekan kerja dalam melayani dengan tujuan agar dapat menolong dan memungkinkan dia dalam menyelesaikan masalah, membuat keputusan dan hal-hal lainnya yang menyangkut kerjasama. Dalam suratsuratnya, tidak sedikit tokoh-tokoh yang disebutkan, mendampingi Paulus dalam perjalanan pemberitaan Injil, seperti: Barnabas, Timotius, Titus maupun Silas.

\section{Pola Mentoring}

Dalam pelayanannya, Paulus sangat memperhatikan jemaat-jemaatnya. Untuk melayani jemaat-jemaat yang pernah dilayaninya

${ }^{19}$ Eddie Gibbs, Kepemimpinan Gereja Masa Mendatang: Membentuk Dan Memperbarui Kepemimpinan Yang Mampu Bertahan Dalam Zaman Yang Berubah (Jakarta: BPK Gunung Mulia, 2011), 21. 
maka salah satu cara agar jemaat tersebut semakin bertumbuh dan tetap di dalam Kristus, maka Paulus sebelumnya 'mempersiapkan' seseorang sebelum melayani jemaat tersebut. Pola mentoring menjadi cara yang tepat bagi Paulus dalam mempersiapkan pribadi tersebut. Istilah mentoring berasal dari kata mentor yang artinya penasihat atau penolong. Dalam konsep keseluruhan dapat juga disebut sebagai pembimbingan. Pembimbingan adalah suatu kegiatan memberi nasihat, arahan, pertolongan yang terarah dengan integritas yang tinggi sehingga orang lain mengalami kemajuan dan berubah ke arah yang lebih baik dan tepat. ${ }^{20}$

Dalam kepemimpinan Paulus, tidak dijelaskan secara eksplisit mengenai pola 'mentoring'. Namun dalam hubungannya dengan Timotius (anak rohaninya), konsep mentoring yang dinyatakan oleh Paulus dapat terlaksana. Timotius adalah orang yang dapat dipercaya namun kurang bersemangat. Ia terkesan sebagai seseorang yang belum dewasa meskipun ia pasti telah berusia sekurang-kurangnya 30 tahun ketika Paulus menugaskan dia untuk memimpin gereja di Efesus (1 Tim. 4:12). Ia penakut (2Tim. 1:6,7) dan sering terganggu pencernaannya (1 Tim. 5:23). Surat yang memakai namanya ini dimaksudkan untuk membesarkan hati dan meneguhkan dia untuk menerima tugas berat yang dilimpahkan Paulus kepadanya. Paulus membagikan pengalaman serta penerapan mengenai pelayanan kepada Timotius. ${ }^{21}$ Dan pada akhirnya, setelah menerima peneguhan mengenai pelayanan, Paulus memberikan kewenangan dan tanggung jawab kepada Timotius untuk melayani jemaat di Efesus agar mereka bertumbuh di dalam Kristus.

\section{Pola Alih Generasi}

Dalam pelayanannya, Paulus sangat memerhatikan yang namanya alih generasi, yakni 'menciptakan' pemimpin-pemimpin agar berita Injil tetap diberitakan. Rasul Paulus terus mengembangkan para pemimpin jemaat melalui surat-suratnya, dengan tujuan adanya alih generasi dalam kepemimpinan dari Paulus ke pemimpin yang baru. Searah dengan hal tersebut, Petrus Octavianus menyatakan bahwa: "Paulus mengembangkan orang-orang sedemikian rupa sehingga mereka dapat memimpin orang lain. Paulus mengunjungi para pemimpin dalam jemaatnya untuk menanyakan perkembangan mereka, memberikan dorongan dan mengarahkan." ${ }^{22}$

Paulus menyadari bahwa hidupnya tidak akan lama lagi dan hukuman mati siap untuk diterimanya. Oleh karena itu, Paulus mempersiapkan Timotius (salah satu pemimpin jemaat) sebelum masuk dalam pelayanan menggembalakan jemaat. Paulus merasa perlu menguatkan dan mempersiapkan Timotius untuk menghadapi setiap masalah yang akan dihadapinya ketika melayani jemaat.

\section{Kompetensi Interpersonal Paulus}

Kompetensi interpersonal adalah kapasitas dalam diri seseorang yang mencakup kualitas pengetahuan, karakter dan keahlian yang diekspresikan ketika membangun relasi atau hubungan dengan sesama. Berbicara mengenai kompetensi interpersonal Paulus, maka ada beberapa hal yang dideskripsikan, yakni: faktor pembentuk, bentuk-bentuk kompetensi interpersonal Paulus dan dampaknya dalam pelayanan pastoral.

\section{Faktor Pembentuk Kompetensi Interpersonal} Paulus

Dalam kehidupan Paulus, faktor perjumpaan pribadi dengan Yesus, keluarga, pendidikan dan sosio budaya pada masa itu, sangat mempengaruhi kompetensi interpersonal yang dimilikinya.
${ }^{20}$ Petrus Octavianus, Alih Generasi Dan Kepemimpinan Dalam Garis Firman Allah (Batu: Petrus Octavianus Institut, n.d.), 76.
${ }^{21}$ Tenney, Survey Perjanjian Baru, 413-422.

${ }^{22}$ Octavianus, Alih Generasi Dan Kepemimpinan Dalam Garis Firman Allah, 234. 


\section{Perjumpaan Pribadi Dengan Yesus Kristus}

Pada dasarnya, perjumpaan Paulus secara pribadi dengan Yesus sangat berkontribusi dalam membentuk kompetensi interpersonal dalam dirinya. Perjumpaannya dengan Kristus mengubah orientasi hidupnya. Baginya sekarang hidup adalah Kristus dan mati adalah keuntungan (Flp. 1:21). Hal ini berarti, Paulus menunjukkan karakter yang setia dalam meresponi panggilan Tuhan dalam hidupnya. Walaupun nyawa menjadi taruhannya, ia tetap setia untuk mengabdi dan melayani Tuannya.

Selain itu, melalui peristiwa perjumpaan tersebut, Paulus mengalami pembentukan Tuhan, sehingga ia menyadari siapa dirinya, latar belakang keyahudiannya yang keras dan pada akhirnya menjadi pribadi yang lembut dan rendah hati. Peristiwa perjumpaan dengan Tuhan juga membentuk hubungan inter-personal Paulus dengan pribadi-pribadi dan jemaat yang dilayani. Jadi, dapat disimpulkan bahwa penggembalaan yang dilakukan Yesus terhadap Paulus sangat berpengaruh terhadap pembentukan dan pengembangan kompetensi interpersonalnya.

\section{Faktor Keluarga}

Faktor keluarga juga turut mempengaruhi perkembangan kompetensi interpersonal dalam diri Paulus. Mengenai kompetensi karakter yang dimilikinya, faktor keturunan dan pengalaman awal masa kecil sangat memengaruhi pembentukan karakter Paulus. Selanjutnya, pada masa kanak-kanak, orang tuanya sangat berpengaruh dalam proses perkembangan kompetensi pengetahuannya. Berdasarkan adat istiadat Yahudi, setiap ayah Yahudi memusatkan perhatian pada pendidikan Kitab suci kepada anak-anaknya. Hal ini searah dengan apa yang disampaikan oleh Robinson Rimun bahwa orang tuanya pasti mengajarkan Taurat. ${ }^{23}$ Paulus mendapat pendidikan agama Yahudi secara ketat

${ }^{23}$ Robinson Rimun, "Latar Belakang Hidup Dan Pendidikan Rabinik Paulus Dalam Kaitannya Dengan Perjumpaannya Dengan Kristus," PASCA: Jurnal Teologi dan Pendidikan Agama Kristen 15, no. 2 (2019): 1-8.

${ }^{24}$ Yacobus Hariprabowo, "Sang Misionaris Agung," Logos, Jurnal Filsafat - Teologi 7, no. 1 (2009): 20, dalam keluarganya, sehingga dia tumbuh menjadi seorang Yahudi yang taat. ${ }^{24}$ Sebab, kebanggaan terbesar mereka adalah mendidik anak-anaknya supaya taat pada hukum dan ibadat yang telah diturunkan..$^{25}$

Pengajaran Taurat ini diajarkan berulangulang kepada anak-anak dalam segala keadaan agar firman Tuhan itu benar-benar melekat di hati dan pikiran anak-anak keturunan Israel, termasuk Paulus semasa kecilnya. Hal ini memengaruhi kompetensi interpersonal Paulus dalam pelayanan, secara khusus dalam bidang pengajaran firman Tuhan. Jadi pada dasarnya kompetensi interpersonal Paulus terbentuk oleh faktor internal yang mencakup faktor bawaan yang terjadi sejak dalam kandungan. Selain itu dalam proses perkembangan, faktor lingkungan keluarganya berdasarkan adat istiadat dan tradisi, juga berpengaruh dalam kompetensi interpersonalnya.

\section{Faktor Pendidikan}

Kompetensi interpersonal pemimpin pastoral dapat tumbuh dan berkembang apabila pemimpin tersebut mau membekali diri demi pelayanan Kristen dengan mempelajari pendidikan dari beragam disiplin akademis yang luas, diikuti pendidikan yang terspesialisasi di bidang teologi dan pelayanan. ${ }^{26}$ Kompetensi interpersonal yang dimiliki oleh Paulus, tidak lepas dari pendidikan yang diterimanya sejak kecil melalui orangtuanya sampai dewasa. Sejak usia enam tahun, Paulus sudah menerima pendidikan yang baik tentang tradisi Yahudi dan hukum Taurat di Sinagoge, sebagaimana anak-anak lelaki Yahudi pada waktu itu. Sehingga, Paulus memiliki pengetahuan hukum Taurat dan Perjanjian Lama edisi bahasa Yunani (LXX), yang

http://ejournal.ust.ac.id/index.php/LOGOS/article/view /263/pdf Dx.

${ }^{25}$ A. Brunot, Paulus Dan Pesannya (Yogyakarta: Penerbit Kanisius, 1992), 17.

${ }^{26}$ Trull and Carter, Etika Pelayan Gereja: Peran Moral Dan Tanggung Jawab Etis Pelayan Gereja, 41. 
mendalam dalam dirinya. ${ }^{27}$ Pada usia remaja, Paulus dididik oleh seorang rabi yang terkenal dan sangat dihormati bernama Gamaliel (Kis. 5:33). Ia adalah anggota Sanhedrin, badan keagamaan yang berkuasa dalam Yudaisme (Kis. 5:34) ${ }^{28}$ John Pollock seperti yang dikutip oleh Charles Swindoll menyatakan bahwa:

\begin{abstract}
Menjelang ulang tahunnya yang ketiga belas, Paulus telah paham betul sejarah yahudi, sajaksajak Mazmur dan kepustakaan para nabi yang luar biasa. Telinganya sangat terlatih dalam keakuratan bunyi, dan daya tangkap otaknya dapat menyimpan apa yang ia dengar dengan cepat dan tepat sebagaimana "alat fotografi modern" merekam sebuah foto yang akan dicetak. Ada kemungkinan pada tahun 14 Masehi, ketika Agustus wafat, Paulus remaja diutus melalui lautan ke Palestina untuk mendaki bukit-bukit menuju ke Yerusalem untuk terlibat dalam filosofi moral penyembah berhala. Dan selama 5 atau 6 tahun berikutnya, ia duduk di kaki Gamaliel, cucu Hillel, guru tertinggi, yang beberapa tahun sebelumnya telah wafat di usia lebih dari 100 tahun. $^{29}$
\end{abstract}

Selama pendidikan tersebut, Paulus banyak bergelut dengan penafsiran Kitab Suci yang rumit dan menerapkannya untuk menanggapi persoalan-persoalan konkret yang muncul pada waktu itu. Paulus membutuhkan waktu sekitar 5 tahun $(20$ - 25 M) untuk menyelesaikan pendidikannya. Pendidikan ini besar sekali pengaruhnya bagi Paulus, khususnya dalam mempertahankan ajaran.

Selain itu, kompetensi pendidikan Paulus juga dipengaruhi oleh buku-buku yang dibacanya. Searah dengan hal tersebut, Richard Clinton dan Paul Leavenworth menyatakan bahwa salah satu karakteristik pemimpin yang mampu menyelesaikan pelayanannya dengan tuntas adalah memelihara suatu sikap belajar dan belajar dari berbagai sumber seperti kehidupan itu sendiri, orang lain dan literatur. ${ }^{30}$ Surat 2 Tim. 4:13, merupakan permintaan Paulus pada waktu dia berada di penjara. Pesan tersebut disampaikan

${ }^{27}$ Octavianus, Alih Generasi Dan Kepemimpinan Dalam Garis Firman Allah.

${ }^{28}$ Pate C. Marvin, Teologi Paulus (Malang: Gandum Mas, 2004), 21.

${ }^{29}$ Charles R. Swindoll, Paulus: Seorang Yang Penuh Kasih Karunia Dan Tegar (Jakarta: Nafiri Gabriel, 2004), 10. 11. kepada Timotius, ketika hendak datang menemuinya, yakni: "Jika engkau ke mari bawa juga ... kitab-kitabku, terutama perkamen itu." Berdasarkan permintaan Paulus kepada Timotius ini, Daniel Lukas Lukito berpendapat bahwa: Pertama, bagi Paulus, buku adalah bagian dari kehidupan yang esensial atau penting sifatnya. Kedua, bagi Paulus semua orang boleh meninggalkan dia, rekan kerja boleh pergi ke tempat yang lain, tetapi harus ada buku yang menemani untuk menghangatkan kehidupan. Ketiga, bagi Paulus sekalipun buku-buku adalah penting tetapi Kitab itu yang adalah firman Tuhan merupakan bagian yang paling utama. ${ }^{31}$ Jadi, faktor pendidikan baik itu kebiasaan untuk belajar Taurat sejak kecil, Guru yang mengajar dalam hal ini Gamaliel maupun buku-buku bacaan yang dibaca olehnya, sangat berpengengaruh terhadap kompetensi pendidikan yang dimiliki oleh Paulus.

\section{Faktor Sosio-Budaya}

Tempat kelahiran Paulus yang adalah Tarsus merupakan sebuah kota besar yang sibuk dengan beragam budaya dan perdagangan internasional. Karena dekat dengan pelabuhan laut, Tarsus menjadi rute perdagangan yang populer bagi para kafilah yang membawa barang dagangan mereka dari Asia Timur menuju Roma di bagian barat. Hal ini memungkinkan Paulus untuk dapat melihat dan memahami budaya serta memperoleh pengetahuan yang baru melaluinya. Di samping itu, Tarsus menjadi kota pusat perdagangan dan juga menjadi kota ilmu pengetahuan. Banyak orang pendatang yang belajar di sekolah-sekolah terkenal di Tarsus, dan kemudian tersebar ke seluruh bagian kekaisaran Roma. Di kota ini tinggal orang-orang Yunani dan orang- orang Timur, juga bangsa-bangsa yang lain. Selain itu, Paulus juga mendapat kesempatan belajar tentang cara hidup bangsa 20.

${ }^{30}$ Clinton and Leavenworth, Memulai Dengan Baik,

${ }^{31}$ Daniel Lukas Lukito, "Hamba Tuhan Dan Bacaannya," Veritas 1 (2001), 231-235. 
yang bukan Yahudi. ${ }^{32}$ Oleh karena itu, ketika waktunya tiba, dia dapat memperkenalkan Injil Kristus kepada bangsa-bangsa lain dengan cara yang sangat baik.

Pada masa Paulus, kebudayaan Yunani mendominasi dunia dari tahun 331 - 63 sM. Sumbangan-sumbangan utamanya kepada masyarakat meliputi: menetapkan satu bahasa umum; pembauran retorikan dan usaha-usaha memahami pertanyaan-pertanyaan filosofis yang diajukan oleh Sokrates, Plato, Aristoteles, dan lain-lain; kesetiaan pada dewa-dewa suatu bangsa; dan penekanan pada kota atau polis, sebagai pusat integratif dari penduduk. Dan kebudayaan Yunani ini sangat berpengaruh bagi kehidupan Paulus, ${ }^{33}$ secara khusus dalam pengembangan kompetensi interpersonal dirinya.

Bentuk-Bentuk Kompetensi Interpersonal Paulus

Dalam surat-surat kiriman Paulus, selain memberikan wawasan tentang mengapa pemimpin itu ada, juga menambahkan wawasan mengenai kemampuan/ kompetensi interpersonal yang harus dimiliki oleh seorang pemimpin; baik itu menyangkut kompetensi pengetahuan, karakter dan keahlian.

\section{Kompetensi Pengetahuan}

Berbicara mengenai kompetensi pengetahuan, maka landasan bagi kompetensi ini adalah Tuhan yang adalah Sumber Kebenaran (1 Sam. 7:28; Yoh. 14:6; 37:23; Mzm. 111:7,8; 119:160; Yes. 5:7, 16; 9:7; 33:5; 45:23). Kekuatan kebenaran yang bersumber dari Tuhan ini meneguhkan kompetensi pengetahuan yang berfungsi sebagai 'jembatan perantara' bagi sifat, sikap, kehendak, perasaan, kata serta perbuatan pemimpin.

Kompetensi pengetahuan melingkupi isi, sifat khas dan dinamika pikiran, yang menjadi dasar bagi autentisitas, nilai serta kekuatan berpikir. Dalam hubungan ini, kompetensi pengetahuan memberikan penguatan bagi pemimpin untuk

\footnotetext{
${ }^{32}$ Swindoll, Paulus: Seorang Yang Penuh Kasih Karunia Dan Tegar, 8-9.

${ }^{33}$ Marvin, Teologi Paulus, 15.
}

berpikir benar, baik dan sehat. Pada sisi yang lain, integritas intelektual ini pada akhirnya berujung kepada lahirnya "pikiran, kehendak, perasaan dan tindakan berkualitas" yang agung dan anggun yang membawa pemimpin kepada keberhasilan kepemim-pinannya.

Dalam pelayanan Paulus sebagai pemimpin Pastoral, ia diperlengkapi dan diperkaya dengan ilmu pengetahuan. Hal ini memungkinkan Paulus untuk "jujur" dan disiplin terhadap kebenaran dalam berapolegetika dan mengajar serta memuridkan jemaat yang dilayaninya (Kisah Para Rasul 13:14, 15, 23, 25, 27, 28, 30, 33, 38). Mengajar merupakan tugas yang penting bagi pemimpin gereja. Sebab, melalui mengajar kebenaran yang didasarkan oleh firman Tuhan, "worldview" dan doktrin yang benar dapat ditanamkan dalam kehidupan jemaat sehingga penyesatan dapat ditangkal, informasi yang membingungkan dan menye-satkan dapat dihadapi dengan sehat. Jadi kompetensi pengetahuan yang dimiliki oleh Paulus sangat berpengaruh dalam pelayanan yang dikerjakannya, baik kepada dirinya, rekan pelayanan maupun jemaat yang dilayani. Kompetensi ini memungkinkannya memberitakan kebenaran firman Tuhan dengan jujur dan konsisten.

\section{Kompetensi Karakter}

Dalam kepemimpinan, seorang pemimpin dituntut agar memiliki kepribadian dan karakter yang baik. Sebab, melalui karakter yang baik akan menciptakan kepercayaan dalam hati mereka yang dipimpinnya. ${ }^{34}$ Ada beberapa karakter Paulus yang menunjukkan kompetensi interpersonal dalam dirinya dan dapat menjadi acuan kompetensi interpersonal pemimpin gereja dalam melayani, yakni:

\section{Bekerja Keras}

Bekerja keras ialah sungguh-sungguh bekerja, yakni berusaha menyelesaikan tugas dengan

\footnotetext{
${ }^{34}$ A.M. Mangunhardjana, Kepemimpinan (Yogyakarta: Penerbit Kanisius, 1986), 12.
} 
penuh tanggung jawab. Di dalam Alkitab, semua pemimpin yang berhasil karena bekerja keras disamping berdoa sebagai prioritas utama dalam kepemimpinannya. Karakter Paulus sebagai seorang pekerja keras, dapat menjadi contoh bagi pemimpin gereja masa kini dalam melayani. Bagi Paulus kepemimpinan itu bukan sebuah jabatan yang membebaskan dia dari tugas dan kewajiban demi memusatkan perhatiannya pada pekerjaan yang lebih penting. Dalam 1 Kor. 15:10, dikatakan: "... aku telah bekerja lebih keras lebih dari pada mereka semua ..." Istilah "aku telah bekerja keras" berasal dari bahasa Yunani

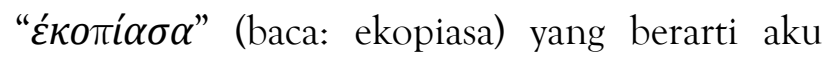
telah berjerih lelah. ${ }^{35}$

Selain itu, walaupun harus melalui beragam penderitaan dan penganiayaan, Paulus tetap melakukan pelayanannya. Paulus tetap bekerja keras untuk mengkomunikasikan Injil, walaupun harus menerima penolakan demi penolakan. Sebagai pemimpin Kristen, sudah seharusnya memberikan contoh dengan bekerja keras, sehingga orang-orang yang dipimpin juga meneladani untuk bekerja keras dalam melayani.

Setia

Kesetiaan Paulus untuk melayani Tuhan teruji ketika gereja menolak kepemimpinannya, meragukan motivasinya, mengejek khotbahnya dan menolak setiap usaha rekonsiliasi dari padanya. Penolakan-penolakan ini dialami oleh Paulus ketika melayani jemaat di Korintus. $^{36}$ Namun, oleh karena Paulus mau setia kepada Oknum (Kristus) yang telah memanggil dan mengutusnya untuk mengerjakan tugas kerasulan, maka ia juga setia kepada jemaat yang dilayaninya, walaupun jemaat tersebut menolak kehadirannya. Paulus tanpa keraguan mengatakan bahwa dia adalah manusia di bawah perintah. Naluri pengabdiannya sedemikian kuat hingga dia sering menggambarkan dirinya sebagai hamba Kristus (Rm. 1:1). ${ }^{37}$

Selain itu, ketika Paulus berada di dalam penjara, ia tetap setia menjadi mentor bagi anak

\footnotetext{
${ }^{35}$ Hasan Sutanto, Perjanjian Baru Yunani-Indonesia Dan Konkordansi Perjanjian Baru (PBIK) Jilid 1 (Jakarta: LAI, 2003), 12.
}

rohaninya, seperti Timotius serta memperhatikan dan melayani jemaat-jemaatnya. Nasihat Paulus kepada Timotius di dalam 2 Tim. 2:22, "Sebab itu jauhilah nafsu orang muda, kejarlah keadilan, kesetiaan, kasih dan damai bersamasama dengan mereka yang berseru kepada Tuhan dengan hati yang murni." Salah satu hal yang ditekankan oleh Paulus dalam ayat ini adalah kejarlah kesetiaan yang dapat berarti bertahan sampai akhir. Seorang pemimpin tidak saja harus memulai tugasnya dengan baik, tetapi ia harus mengerjakannya dengan baik pula sampai akhir. Kesetiaan Paulus dalam melayani, baik kepada Kristus maupun kepada jemaat yang dilayani dapat menjadi cerminan kompetensi karakter yang harus dimiliki pemimpin gereja masa kini.

\section{Berbelas Kasihan}

Dalam kepemimpinan yang berbelas kasihan, seorang pemimpin bertindak untuk kepentingan para pengikut serta organisasi yang dipimpinnya. Pada masa pelayanan Paulus, orang-orang Kristen Yahudi di dekat Yerusalem berada dalam masalah kelaparan. Paulus menyebut mereka sebagai "orang-orang miskin di antara orang-orang kudus di Yerusalem" (Rm. 15:26). Sebagai pemimpin, Paulus merasa bertanggung jawab terhadap orangorang yang pernah dilayaninya. Dalam hal ini, yang dilakukan oleh Paulus adalah mengumpulkan persembahan untuk orang miskin dan ia mendesak pertanggungan jawab orang percaya lainnya untuk membantu mereka yang membutuhkan. Dia mencari kesempatan bagi orang-orang Kristen non-Yahudi untuk menjangkau dengan belas kasihan serta untuk menunjukkan kesatuan rohani. Paulus tidak menggerakkan kegiatan amal massal melalui surat, tetapi dia menekankan secara langsung adanya kebutuhan dana ( $\mathrm{Rm}$ 15:25-26; 1 Kor. 16:1; 2 Kor. 8:1-9:15).

Dalam 2 Kor. 9:6, Paulus memperluas seruannya ini sedikit lebih jauh dengan menggambarkan upah-upah dari memberi, "Orang yang menabur sedikit, akan menuai sedikit juga, dan orang yang menabur banyak,

\footnotetext{
${ }^{36}$ Fisher, The 21st Century Century Pastor: Sebuah Visi Berdasarkan Pelayanan Rasul Paulus, 103.

${ }^{37}$ Ibid, 103.
} 
akan menuai banyak juga." Paulus menunjukkan bahwa kemurahan hati membawa keuntungan bagi pemberi karena persembahan bisa berfungsi sebagai penyembahan kepada Tuhan dan bisa menginspirasi iman orang lain. Hanya melalui kompetensi karakter yang berbelas kasihan memungkinkan Paulus untuk menyatakan kasih kepada jemaat yang dilayaninya. Selain itu, karakter yang berbelas kasihan dinyatakan melalui mengajak jemaat lainnya untuk terlibat dalam proyek kasih yang sedang direncanakan oleh Paulus.

\section{Rendah Hati}

J. Oswald Sanders seperti dikutip oleh P. Octavianus menyatakan bahwa dalam perspektif Allah, kerendahan hati mendapat tempat yang sangat tinggi, tidak menonjolkan diri. ${ }^{38}$ Seorang yang rendah hati bukanlah seseorang yang hanya mencari ketenaran maupun kedudukan.

Paulus adalah seorang pemimpin yang rendah hati. Beberapa pernyataan Paulus yang menunjukkan karakternya yang rendah hati adalah pada permulaan pelayanan Paulus, sementara ia mengingat kisah hidupnya yang telah lalu dan yang sekarang sangat dibencinya, ia mengaku, "karena aku adalah yang paling hina dari semua rasul, sebab aku telah menganiaya jemaat Allah" (1 Kor. 15:9). Beberapa waktu kemudian ia berkata, "kepadaku, yang paling hina di antara segala orang kudus, telah dianugerahkan kasih karunia ini, untuk memberitakan kepada orang-orang bukan Yahudi kekayaan Kristus, yang tidak terduga itu" (Ef. 3:8). Ketika umurnya semakin lanjut, dan ia sedang mempersiapkan diri untuk bertemu dengan Tuhan, ia berkata dengan sedih, "perkataan ini benar dan patut diterima sepenuhnya: Kristus Yesus telah datang ke dunia untuk menyelamatkan orang berdosa, dan di antara mereka akulah yang paling berdosa" (1 Tim. 1:15). ${ }^{39}$ Jadi, kerendahan hati Paulus sebagai pemimpin pastoral, sama seperti kerohaniannya menjadi sifat yang terus bertumbuh dalam kepemimpinan pastoralnya.

${ }^{38}$ Octavianus, Alih Generasi Dan Kepemimpinan Dalam Garis Firman Allah, 227.

\section{Berintegritas}

Pemimpin yang memiliki integritas adalah pemimpin yang "dapat dipercaya." Pemimpin yang berintegritas adalah seorang yang mempunyai kepribadian utuh dalam kata dan perbuatan. Sebagaimana perilakunya di depan umum, begitulah kenyataan kehidupannya. Dalam hal integritas, seorang pemimpin dapat melihat beberapa nasihat Paulus.

Menurut Paulus, kehidupan seorang pemimpin adalah seperti surat Kristus yang terbuka yang dikenal dan dibaca oleh semua orang (2 Kor. 3:2). Hal ini menunjukkan bahwa seorang pemimpin yang berintegritas harus hidup berdasarkan apa yang diajarkan kepada jemaat dan melakukan sesuai dengan apa yang dikatakan. Selanjutnya, dalam 2 Tim. 2: 2, Paulus memberi nasihat kepada Timotius: "Apa yang telah engkau dengar dari padaku di depan banyak saksi, percayakanlah itu kepada orang-orang yang dapat dipercayai, yang juga cakap mengajar orang lain.” Nasihat Paulus yang ditujukan kepada Timotius, menunjukkan bahwa Paulus adalah seorang pemimpin yang berintegritas baik dalam hal pengajaran maupun tindakan. Selain itu, nasihat Paulus ini juga merupakan bagian dari mentoring Paulus kepada Timotius agar menjadi pemimpin pastoral yang berintegritas di tengahtengah jemaat.

\section{Hati yang Teguh}

Dalam 2 Tim. 2:9-10 Paulus menekankan tentang keteguhan hati dalam melayani. Hal ini menunjukkan bahwa walaupun harus menghadapi kesulitan dan penderitaan, keteguhan hati untuk memberitakan Injil tidak surut. Ia sabar menanggung semuanya itu agar orang-orang pilihan Allah, memperoleh keselamatan dalam Kristus Yesus.

Pada bagian lain, Rasul Paulus yang akan segera menemui ajalnya mengingatkan Timotius dalam 2 Tim. 3:1-9, yang memungkinkan akan menciutkan nyali seorang pemimpin pastoral, sehingga menjadi bimbang dan putus asa dalam

${ }^{39} \mathrm{~J}$. Oswald Sanders, Kepemimpinan Rohani (Bandung: Kalam Hidup, 1979), 63. 
melayani Tuhan. Menghadapi hal ini, Rasul Paulus mengatakan kepada Timotius, demikian: "Tetapi engkau telah mengikuti ajaranku, cara hidupku, pendirianku, imanku, kesabaranku, kasihku dan ketekunanku. Engkau telah ikut menderita penganiayaan dan sengsara seperti yang telah kuderita di Antiokhia dan di Ikonium dan di Listra. Semua penganiayaan itu kuderita dan Tuhan telah melepaskan aku dari padanya. Memang setiap orang yang mau hidup beribadah di dalam Kristus Yesus akan menderitaaniaya, sedangkan orang jahat dan penipu akan bertambah jahat, mereka menyesatkan dan disesatkan. Tetapi hendaklah engkau tetap berpegangpada kebenaran yang telah engkau terima dan engkau yakini, denganselalu mengingat orang yang telah mengajarkannya kepadamu" (2 Tim. 3:10-14). Yang Paulus maksudkan di sini ialah bahwa pemimpin yang berintegritas, yang dapat dipercayai akan tetap teguh hatinya, walaupun ia mengalami tantangan dalam pelayanannya, bahkan tantangan yang hebat sekalipun.

\section{Kompetensi Keahlian}

Pemimpin bukanlah orang yang hanya bisa memberi perintah. Pemimpin adalah seorang yang harus bisa bertindak dan memberi teladan yang baik bagi mereka yang dipimpinnya. Dalam hal ini, kompetensi keahlian dalam memimpin sangat dibutuhkan oleh seorang pemimpin. Kompetensi keahlian dapat berkenaan dengan sejauh mana penerapan karakter dan pengetahuan secara praktis dalam kepemimpinan. Ada beberapa kompetensi yang dimiliki Paulus berhubungan dengan keahliannya sebagai pemimpin pastoral, yakni:

\section{Kecakapan Memimpin}

Berbicara mengenai kecakapan dalam memimpin, maka topik ini menyangkut dua hal, yaitu: kecakapan dalam hubungan antar manusia (relationship) dan kecakapan keahlian teknis. Kecakapan yang berkenaan dengan hubungan antar manusia (relationship), atau disebut juga keterampilan atau kecakapan sosial dapat dilihat melalui pelayanan pastoral Paulus, dimana ia adalah seorang yang menekankan tentang pelayanan secara team work. Paulus membutuhkan rekan kerja dalam melayani dengan tujuan agar dapat menolong dan memungkinkan dia dalam menyelesaikan masalah, membuat keputusan dan hal-hal lainnya yang menyangkut kerjasama. Selain itu, dalam pelayanan pastoralnya, Paulus sangat bertanggung jawab dan menjaga relasi dengan jemaat yang dilayaninya. Misalnya, walaupun dalam keadaan terdesak dan berada di dalam penjara, ia tetap membina hubungan dengan jemaat yang dilayaninya. ${ }^{40}$ Selain itu, ketika memberikan perhatian khusus kepada jemaat yang lebih besar, tidak jarang Paulus menjalin komunikasi dengan rekan-rekan pribadinya, seperti Timotius, Titus dan lain-lain. Hal ini berarti ada kaitannya dengan pendelegasian tugas kepada rekan yang dapat dipercaya dan cakap untuk memimpin.

Selanjutnya, kecakapan yang berkaitan dengan "hubungan pelaksanaan tugas" maka, seorang pemimpin yang kompeten, harus tahu dan dapat melakukan tugasnya dengan baik dan benar. Dapat dikatakan bahwa Paulus adalah seorang pemimpin pastoral yang paling berhasil sepanjang zaman. Dalam kurun waktu kurang dari satu generasi, ia mengadakan perjalanan ke seluruh wilayah dunia Laut Tengah, dan mendirikan jemaat-jemaat Kristen yang berkembang serta aktif ke mana pun ia pergi. Dalam hal ini, Paulus menyadari bahwa ia hanya seorang pembawa berita, dan kuasa Roh Kudus sematalah yang membawa perubahan dalam kehidupan orang yang ditemuinya.

\section{Kecakapan Mengkomunikasikan Injil}

Berbicara mengenai kompetensi interpersonal yang menyangkut keahlian secara khusus ketika mengkomunikasikan Injil, Paulus adalah seorang ahli strategi yang ulung. Dalam melakukan perjalanan misi, cara-cara mengkomunikasikan Injil didasarkan atas

\footnotetext{
${ }^{40}$ Jemaat yang dilayani ketika Paulus di dalam penjara adalah jemaat Efesus, Filipi dan Kolose.
} 
pengertian yang luas tentang proses orang berpikir dan mengambil keputusan.

Selanjutnya, Paulus juga menyadari bahwa dalam menyajikan berita Injil diperlukannya variasi, disesuaikan dengan konteks di mana ia memberitakan Injil. Di Sinagoge di Tesalonika, ia mulai dengan Perjanjian Lama (Kis. 17:2-3). Di Atena, ia mulai dengan "Allah yang tidak dikenal, yang dicari oleh orang-orang Yunani (Kis. 17:2231). Di Efesus, ia bersedia terlibat dalam perdebatan di depan umum tentang makna Injil Kristen (Kis. 19:9). ${ }^{41}$ Artinya, kompetensi interpersonal yang dimiliki oleh Paulus, memungkinkannya mengkomunikasi-kan Injil dalam budaya dan adat istiadat yang berbeda.

\section{Dampak Kompetensi Interpersonal Paulus Sebagai Pemimpin Pastoral}

Bagi Paulus, kompetensi interpersonal yang ada pada dirinya sebagai pemimpin pastoral, membawa dampak, baik bagi dirinya, rekan pelayanan maupun bagi jemaat yang dilayani.

\section{Bagi Paulus}

Paulus adalah seorang pemimpin yang diperlengkapi dengan kompetensi interpersonal, baik pendidikan, karakter maupun keahlian. Dengan kompetensi yang dimilikinya, berdampak pada pelayanan yang dikerjakannya. Sebagai pemimpin jemaat yang kompeten, tidak sedikit jemaat yang dikunjunginya menerima kehadirannya dan pengajaran yang disampaikannya. Selain itu, dampak bagi dirinya adalah kemampuannya dalam bertanya jawab, berapolegetika serta mensharingkan kebenaran Injil kepada orang-orang percaya maupun yang tidak percaya. Terhadap ajaran-ajaran sesat serta filsafat Yunani yang sedang berkembang pada waktu itu, kompetensi pendidikan yang dimiliki Paulus, memungkinkannya untuk dapat menangkal ajaran-ajaran tersebut dengan pengetahuan firman Tuhan yang dimilikinya serta memberikan nasihat, baik kepada rekan-

\footnotetext{
${ }^{41}$ John Drane, Memahami Perjanjian Baru (Jakarta: BPK Gunung Mulia, 1996), 344-345.

${ }^{42}$ Octavianus, Alih Generasi Dan Kepemimpinan Dalam Garis Firman Allah, 315.
}

rekan pelayanan maupun kepada jemaat-jemaat agar tidak terjebak kepada ajaran-ajaran tersebut. Kompetensi pengetahuan rasul Paulus juga terefleksi dalam pemecahan berbagai masalah dalam jemaat-jemaat yang dilayaninya. ${ }^{42}$ Artinya, Paulus memiliki kemampuan dalam menyelesaikan masalah demi masalah yang dihadapi jemaat yang dilayaninya.

Pada waktu mengkomunikasikan Injil, Paulus selalu menyesuaikan (beradaptasi) dengan konteks di mana ia berada (1 Kor. 9:19-23). Paulus mengenal siapa yang pendengarnya dan alamat-alamat para pendengarnya. Paulus mempunyai prinsip-prinsip hidup yang konstekstual tanpa kompromi dengan iman Kristen. ${ }^{43} \mathrm{Hal}$ ini, searah dengan pendapat David Fisher, yakni:

Khotbahnya (Paulus) di Bukit Mars di Yunani adalah contoh klasik dari adaptasi budaya. Dia tahu benar kepada siap dia berbicara dan dia membuat khotbahnya dapat dimengerti oleh mereka. Dia memulai khotbahnya di dalam dunia mereka dan memindahkan mereka ke dunia Injil. Minggu berikutnya, Paulus berbicara kepada orang Yahudi di sebuah Sinagoge di Korintus dan dia menggunakan pola-pola pemikiran dan bahasa yang berbeda untuk menyampaikan maksud yang sama. $^{44}$

Jadi, kompetensi interpersonal yang dimiliki Paulus, memungkinkannya untuk mengkomunikasikan Injil kepada banyak orang walaupun adat istiadat dan budaya penerimanya berbeda.

\section{Bagi Rekan Pelayanan}

Kompetensi interpersonal Paulus sebagai pemimpin pastoral juga berpengaruh bagi rekan sepelayanannya. Melalui kompetensi yang dimilikinya, hubungan Paulus dengan rekanrekan sepelayanannya begitu dekat satu dengan yang lainnya serta mengakibatkan pertumbuhan

\footnotetext{
${ }^{43}$ Bangun, Integritas Pemimpin Pastoral, 73.

${ }^{44}$ Fisher, The 21st Century Century Pastor: Sebuah Visi Berdasarkan Pelayanan Rasul Paulus, 43.
} 
rohani secara pribadi. ${ }^{45}$ Setelah mengalami pertumbuhan rohani secara pribadi melalui pelayanan pemuridan yang dilakukannya, rekanrekan Paulus meresponi akan mandat yang diberikannya untuk fokus melayani jemaat yang pernah dikunjunginya dan mengembangkan kepemimpinan untuk gereja mula-mula ini. ${ }^{46} \mathrm{Hal}$ ini dapat dilihat dari komitmen Timotius untuk melayani jemaat Efesus dan Titus yang fokus melayani jemaat Korintus. Searah dengan hal tersebut, Petrus Octavianus menyatakan, bahwa:

Berpergian bersama Paulus menyebabkan Timotius berhubungan dengan semacam orang, yaitu orangorang yang kepribadian dan prestasinya dapat membangkitkan antusias yang bermanfaat. Dari Paulus, ia belajar menghadapi krisis dan menang, yang bagi kehidupan dan pelayanan Paulus merupakan hal yang rutin. Aada tradisi yang mengatakan bahwa setelah Paulus mati, Timotius memelihara jemaat Efesus. ${ }^{47}$

Jadi, dalam hal ini, Timotius menyimak dan berusaha meniru kelakuan atau cara hidup Paulus. Tujuan hidup yakni ambisi rohani yang memotivasi Paulus sehingga membuat hidupnya menjadi penuh makna. Dengan cara mengikuti cara hidup Rasul Paulus, maka Timotius telah membuktikan kesejatian kemuridannya. ${ }^{48}$ Kompetensi interpersonal yang dimiliki oleh Paulus dapat menjadi contoh dan teladan bagi rekan-rekan sepelayanan dan untuk selanjutnya menggantikan Paulus untuk menjadi penerus 'tongkat estafet' dalam pemberitaan Injil.

\section{Bagi Jemaat yang Dilayani}

Mengkomunikasikan Injil merupakan pusat dari setiap pembicaraan dalam pertumbuhan atau kesehatan gereja. Gereja tidak akan benar-benar bertumbuh kecuali gereja membuktikan perhatian bersama untuk meneruskan pesannya kepada dunia. $^{49}$ Apabila memperhatikan

${ }^{45}$ Salah satu murid yang diakui oleh Paulus telah mengikuti teladannya adalahTimotius. Hal ini disaksikannya dalam surat penggembalaannya kepada Timotius di dalam 2 Tim. 3:10. Mengikuti cara hidup Paulus berarti menaati keteladanan ketaatannya yang penuh kepada firman Tuhan.

${ }^{46}$ Jenson and Jim, Dinamika Pertumbuhan Gereja, 213. kehidupan jemaat yang dilayani Paulus, kompetensi interpersonal yang dimilikinya sebagai pemimpin pastoral memungkinkan mereka mengalami pertumbuhan; baik secara kuantitatif maupun kualitatif.

Apabila melihat dari segi kuantitatif, bertambahnya orang-orang yang mengambil komitmen untuk menjadi pengikut Kristus merupakan bukti nyata dari pelayanan yang dikerjakannya. Hal ini nampak dari hasil pelayanannya baik kepada kelompok kecil (pribadi-pribadi) maupun kelompok besar jemaat. Searah dengan itu, Gunaryo Sudarmanto, menyatakan bahwa: "Dengan semakin bertambah banyaknya orang menjadi Kristen di Efesus, semakin berkurang jumlah kuil penyembahan di sana." ${ }^{50}$ Hal ini berarti, pertumbuhan jemaat secara kuantitas pada waktu itu, berdampak pada aktivitas jemaat yang mulai meninggalkan segala praktek penyembahan berhala.

Usaha untuk meninggalkan segala bentuk praktek penyembahan berhala, merupakan salah satu bentuk dari pertumbuhan jemaat secara kualitatif. Hal ini menunjukkan bahwa pengajaran yang disampaikan oleh Paulus berdasarkan kompetensi interpersonal yang dimilikinya dapat diterima oleh jemaat dan membuat mereka mengalami pertumbuhan secara rohani. Pertumbuhan jemaat secara kualitatif juga dapat dilihat, pada waktu Paulus menyatakan kekaguman dan sukacitanya sebagaimana ia memberikan pujian kepada gereja di Tesalonika bahwa iman mereka telah terkenal dan telah memberi dampak yang lama terhadap orang-orang yang jauh dari tempat mereka (I Tes. 1:7-8). ${ }^{51}$ Jadi, berita Injil yang disampaikan oleh Paulus, melalui kecakapannya serta keahliannya ketika mengkomunikasikan Injil, memungkinkan banyak gereja bertumbuh dalam iman kepada Kristus.

${ }^{47}$ Octavianus, Alih Generasi Dan Kepemimpinan Dalam Garis Firman Allah, 234.

${ }^{48}$ Ibid, 239.

${ }^{49}$ Jenson and Jim, Dinamika Pertumbuhan Gereja, 241.

${ }^{50}$ Sudarmanto, Menjadi Pelayan Krsitus Yang Baik, 108.

${ }^{51}$ Jenson and Jim, Dinamika Pertumbuhan Gereja, 241. 


\section{KESIMPULAN}

Apabila memerhatikan dinamika kepemimpinan gereja pada saat ini, maka gereja tidak lepas dari krisis kepemimpinan pastoral. Gereja yang seharusnya menghasilkan pemimpin yang memiliki kompetensi interpersonal, malah terkontaminasi dengan berbagai masalah kepemimpinan; sehingga, berdampak dalam pelayanan pastoral. Namun, melalui kajian ini, terkhusus berkaitan dengan pelayanan pastoral Rasul Paulus akan menolong para pemimpin gereja dalam meningkatkan pelayanannya. Selain itu, dengan memahami kompetensi interpersonal yang dimiliki Paulus, yakni kompetensi pengetahuan, karakter dan keahlian dapat menjadikannya sebagai evaluasi dan pengembangan diri untuk meningkatkan kompetensi interpersonal para pemimpin gereja yang pada akhirnya berdampak langsung dalam pelayanan, baik kepada pribadi, rekan pelayanan maupun jemaat yang dilayani.

\section{KEPUSTAKAAN}

Bangun, Yosafat. Integritas Pemimpin Pastoral. Yogyakarta: ANDI, 2010.

Brunot, A. Paulus Dan Pesannya. Yogyakarta: Penerbit Kanisius, 1992.

Clinton, Richard, and Paul Leavenworth. Memulai Dengan Baik. (Jakarta: Penerbit Immanuel, 2004.

Drane, John. Memahami Perjanjian Baru. Jakarta: BPK Gunung Mulia, 1996.

Fisher, David. The 21st Century Century Pastor: Sebuah Visi Berdasarkan Pelayanan Rasul Paulus,. Malang: Penerbit Gandum Mas, 2005.

Gibbs, Eddie. Kepemimpinan Gereja Masa Mendatang: Membentuk Dan Memperbarui Kepemimpinan Yang Mampu Bertahan Dalam Zaman Yang Berubah. Jakarta: BPK Gunung Mulia, 2011.

Hariprabowo, Yacobus. "Sang Misionaris Agung.” Logos, Jurnal Filsafat - Teologi 7, no. 1 (2009): 20.

http://ejournal.ust.ac.id/index.php/LOG OS/article/view/263/pdf Dx.

Jenson, Ron, and Stevens Jim. Dinamika
Pertumbuhan Gereja. Malang: Gandum Mas, 2004.

Lukito, Daniel Lukas. "Hamba Tuhan Dan Bacaannya." Veritas 1 (2001).

Mangunhardjana, A.M. Kepemimpinan. Yogyakarta: Penerbit Kanisius, 1986.

Marvin, Pate C. Teologi Paulus. Malang: Gandum Mas, 2004.

Moleong, Lexy J. Metodologi Penelitian Kualitatif. Edisi Revi. Bandung: Penerbit PT Remaja Rosdakarya, 2010.

Nazir, Mohammad. Metode Penelitian. Jakarta: Gloria Indonesia, 1985.

Octavianus, Petrus. Alih Generasi Dan Kepemimpinan Dalam Garis Firman Allah. Batu: Petrus Octavianus Institut, n.d.

Rianse, Usman. Metodologi Penelitian Sosial Dan Ekonomi: Teori Dan Aplikasi. Bandung: CV. Alfabeta, 2008.

Rimun, Robinson. "Latar Belakang Hidup Dan Pendidikan Rabinik Paulus Dalam Kaitannya Dengan Perjumpaannya Dengan Kristus." PASCA: Jurnal Teologi dan Pendidikan Agama Kristen 15, no. 2 (2019): $1-8$.

Sanders, J. Oswald. Kepemimpinan Rohani. Bandung: Kalam Hidup, 1979.

Sudarmanto, G. Menjadi Pelayan Krsitus Yang Baik. Palembang: Percetakan Monalisa, 2009.

Sudibyo, Tenny, Areyne Christi, Sekolah Tinggi, Teologi Duta, Sekolah Tinggi, and Teologi Excelsius. "Implementasi Prinsip Kepemimpinan Rasul Paulus," no. 2 (n.d.): $1-13$.

Sutanto, Hasan. Perjanjian Baru Yunani-Indonesia Dan Konkordansi Perjanjian Baru (PBIK) Jilid 1. Jakarta: LAI, 2003.

Swindoll, Charles R. Paulus: Seorang Yang Penuh Kasih Karunia Dan Tegar. Jakarta: Nafiri Gabriel, 2004.

Tarmedi, Petrus Alexander Didi. "Analisis Naratif: Sebuah Metode Hermeneutika Kristiani Kitab Suci.” Melintas 29 (2013).

Tenney, Merril C. Survey Perjanjian Baru. Malang: Gandum Mas, 1995.

Trull, Joe E., and James E. Carter. Etika Pelayan Gereja: Peran Moral Dan Tanggung Jawab Etis Pelayan Gereja. Jakarta: BPK Gunung Mulia, 
2013.

VI, Paus Paulus. "Humanae Vitae: Encycal on the Right Ordering of Procreation Children." Acta Apostolociae Sedis 6012 (1968).

Wiyanto, Agus. Rapor Merah Pendeta. Yogyakarta: Gloria Graffa, 2010.

Yayasan, Pengembangan, and Mercy Indonesia.

"Kepemimpinan Rasul Paulus Menurut

Teks 1 Korintus 4 : 1-21 Dalam” 1 (2021): 83-94.

Kamus Besar Bahasa Indonesia. Jakarta: Pusat Bahasa Departemen Pendidikan Nasional, Balai Pustaka, 2001.

Webster's New Encyclopedy Dictionary. New York: Black \& Dog Leventhal Publisher, 1993. 